\title{
Dominant Modes of Tropospheric Ozone Variation over East Asia from GOME Observations
}

\author{
Yi Liu,,2 Yuli Zhang, ${ }^{1,3}$ Yong Wang, ${ }^{1}$ Chuanxi Liu,, ${ }^{1,2}$ Zhaonan Cai, \\ Paul Konopka, ${ }^{4}$ and Rolf Müller ${ }^{4}$ \\ ${ }^{1}$ Key Laboratory of Middle Atmosphere and Global Environment Observation (LAGEO), Institute of Atmospheric Physics, \\ Chinese Academy of Sciences, Beijing 100029, China \\ ${ }_{2}^{2}$ Joint Center for Global Change Studies (JCGCS), Beijing 100875, China \\ ${ }^{3}$ University of Chinese Academy of Sciences, Beijing 100049, China \\ ${ }^{4}$ Institute of Energy and Climate Research: Stratosphere (IEK-7), Forschungszentrum Jülich, 52425 Jülich, Germany
}

Correspondence should be addressed to Zhaonan Cai; caizhaonan@mail.iap.ac.cn

Received 4 February 2015; Accepted 17 April 2015

Academic Editor: Xiaozhen Xiong

Copyright (C) 2015 Yi Liu et al. This is an open access article distributed under the Creative Commons Attribution License, which permits unrestricted use, distribution, and reproduction in any medium, provided the original work is properly cited.

\begin{abstract}
The variation in tropospheric ozone over East Asia was analyzed using tropospheric column ozone data measured by the Global Ozone Monitoring Experiment (GOME) satellite. An empirical orthogonal function (EOF) analysis was carried out to derive the dominant modes of the variation in the tropospheric ozone volume-mixing ratio (TOVMR). The EOF1 mode, which explained $61.5 \%$ of the total variance, showed a same-sign distribution over all of East Asia, with a belt of enhanced ozone concentrations around $40^{\circ} \mathrm{N}$. The principal component of EOF1 (PC1) suggested that photochemical ozone production together with BrewerDobson circulation and subtropical westerly jet plays important roles in modulating the seasonal variation of the TOVMR; ozonerich air produced by photochemical processes was transported from the stratosphere to the troposphere by BD circulation and this ozone-rich air was then blocked by the subtropical westerly jet and accumulated north of the jet. The EOF 2 mode explained $29.2 \%$ of the total variance with an opposite-sign pattern on the north and south side of $35^{\circ} \mathrm{N}$. When anticyclonic circulation transported ozone-poor air from the upwelling area over the Bay of Bengal towards the Tibetan Plateau during the onset of the Asian summer monsoon, tropospheric ozone in this region decreased dramatically.
\end{abstract}

\section{Introduction}

Tropospheric ozone has been considered a greenhouse gas for some time [1]. It has strong effects on radiative forcing [2] and is an important component of the photochemical reactions that occur in the boundary layer [3]. Increasing ozone concentrations in this layer threaten human health and surface ecosystems [4]. Therefore, studies into the spatiotemporal characteristics of tropospheric ozone and its drivers are important theoretically and practically.

With the rapid development of the Asian economies in recent decades, air pollution has increased dramatically [5] and influenced atmospheric chemistry, radiation, and dynamics at regional and global scales. Some air pollutants can directly or indirectly affect ozone concentrations, by influencing the photochemical reactions that generate ozone in the troposphere. Dramatic changes in the concentrations of ozone and its precursors have caused international concern; this has inspired research, including into the effects of increasing air pollution in Asia on ozone concentrations and climate [6], extreme tropospheric ozone events [7], the production, distribution, and evolution of tropospheric ozone [8], cross-tropopause ozone fluxes over east Asia [9, 10], long-range transport of ozone in the East Asian Pacific Rim region [11], tropospheric ozone during the Asian summertime monsoon [12], and tropospheric ozone modeling over Asia [13].

Recently, Randel et al. [14] suggested that tropospheric pollution could be transported into the stratosphere by the Asian summer monsoon and further influence the global atmosphere and climate. However, there are few ozonesonde stations in East Asia and long-term continuous ozone profile 
measurements are especially limited. Because of the lack of sufficient ozonesonde measurements, most researchers who study ozone concentrations over Asia have had to rely on satellite datasets, or limited ground-based measurements.

In this study, the dominant modes of tropospheric ozone variation over Asia were investigated, using empirical orthogonal function (EOF) analysis. Tropospheric column ozone derived from satellite measurements was used to examine the mechanism (photochemistry and transport) behind this variation of the tropospheric ozone over Asia. Section 2 describes the data and methods used. Section 3 describes the seasonality of tropospheric ozone. Section 4 analyzes the dominant modes of the tropospheric ozone variation and their mechanisms. Conclusions are summarized in Section 5.

\section{Data and Methods}

2.1. Satellite Ozone Measurements. The Global Ozone Monitoring Experiment (GOME), on board the European Space Agency (ESA) Remote Sensing-2 (ERS-2) satellite, measured radiance backscattered from the Earth's atmosphere over a wavelength range of $240-790 \mathrm{~nm}$. GOME had a moderate spectral resolution of $0.2-0.4 \mathrm{~nm}$ and high signal-tonoise ratios in ozone absorption bands, making it possible to retrieve the vertical distribution of ozone from the troposphere to the stratosphere [15]. The ozone profile and tropospheric column ozone (TCO) were retrieved from GOME measurements by performing extensive calibration and improvements in the Liu forward model [1618]. Tropopause pressure reanalysis data from the National Centers for Environmental Prediction (NCEP) were used to separate the stratosphere and troposphere.

The retrieved ozone profiles agreed well with measurements from ozonesonde, Total Ozone Mapping Spectrometer (TOMS), and Stratospheric Aerosol and Gas Experiment II (SAGE-II) [16, 19]. Validation with ozonesonde from 33 stations between $75^{\circ} \mathrm{N}$ and $71^{\circ} \mathrm{S}$ during 1996-1999 showed that the retrieved TCO profiles captured most of the temporal variability in ozonesonde TCO; the mean biases were mostly within $3 \mathrm{DU}(15 \%)$ and the $1 \sigma$ standard deviations were within 3-8 DU (13-27\%). We compared GOME ozone profiles to ozonesonde measurements over three stations in China, including Beijing $\left(39.8^{\circ} \mathrm{N}, 116.47^{\circ} \mathrm{E}\right)$ from September 2002 to June 2003, Lhasa $\left(29.7^{\circ} \mathrm{N}, 91.1^{\circ} \mathrm{E}\right)$ from June to October in 1998 and 1999 , and Xining $\left(36.63^{\circ} \mathrm{N}, 101.75^{\circ} \mathrm{E}\right)$ from April to August 1996 [20]. In the middle and lower troposphere, the bias was within $\pm 10 \%$ over Beijing and $\pm 5 \%$ over Lhasa and Xining; in the upper troposphere and lower stratosphere (UTLS), the GOME data had biases of $\pm 10 \%$ over Beijing and positive biases of $10 \%$ over Lhasa and $5 \%$ over Xining; in the middle stratosphere, the GOME retrievals compared well to ozonesonde values over Lhasa but had a negative bias of $10 \%$ over Xining and a positive bias of up to $20 \%$ over Beijing. The mean biases of the TCO were less than $10 \%$ over these three stations.

The spatial resolution of GOME retrievals is normally $960 \times 80 \mathrm{~km}^{2}$. We mapped the swath data from orbits onto a $2^{\circ}$ latitude $\times 2.5^{\circ}$ longitude grid and derived monthly averaged data for March 1996 to June 2003. The TCO was converted from Dobson units to the mean tropospheric ozone volume mixing ratio (TOVMR, in ppbv unit), using the method described by Ziemke et al. [21].

2.2. Definition of Westerly Jet Occurrence. The definition of westerly jet occurrence was based on the methods of Schiemann et al. [22], with the difference being that the wind data used here was in potential temperature $(\theta)$ coordinates rather than pressure coordinates. A four-dimensional index field of jet occurrence, $J(t, x, y, \theta)$, was set to either zero or one, where $t, x$, and $y$ refer to time, latitude, and longitude, respectively. It was set to one when the horizontal velocity $V(t, x, y, \theta)=[u(t, x, y, \theta), v(t, x, y, \theta)]$ satisfied

$$
\begin{gathered}
|V|_{t, x}(y, \theta) \text { is a local maximum, } \\
\qquad V \mid \geq 30 \mathrm{~ms}^{-1}, \\
u \geq 0 \mathrm{~ms}^{-1}
\end{gathered}
$$

and to zero otherwise. Subscripts denote fixed dimensions; that is, $J$ identifies the maxima of the horizontal wind speed in latitude-theta cross sections. The jet identification was carried out between 280 and $400 \mathrm{~K}$, using the European Centre for Medium-Range Weather Forecasts (ECMWF) meteorological ERA-interim reanalysis [23], at time intervals of 6 hours during 1996-2003.

2.3. Definition of Monsoon Index. The Monsoon-Hadley index (MHI), which is based on the anomalous meridional wind shear, was used as a suitable monthly mean monsoon index to describe the intensity of the South Asian (Indian) summer monsoon circulation [24]:

$$
\mathrm{MHI}=V_{850}^{*}-V_{200}^{*},
$$

where $V_{850}^{*}$ and $V_{200}^{*}$ are the regional and temporal mean meridional wind anomalies, at $850 \mathrm{hPa}$ and $200 \mathrm{hPa}$, respectively, over the monsoon region $\left(10^{\circ} \mathrm{N}-30^{\circ} \mathrm{N}, 70^{\circ} \mathrm{E}-110^{\circ} \mathrm{E}\right)$ during April-August.

2.4. Empirical Orthogonal Function (EOF) Analysis. EOF analysis decomposes the space-time field into a set of orthogonal spatial patterns along with a set of associated, uncorrelated, time indices or principal components (PCs) in a linear fashion. The EOF technique aims to find a new set of variables that capture most of the observed variance from the data, through linear combinations of the original variables, or reduce the large number of variables of the original data to a few variables. It has proven to be a powerful tool for identifying dominant modes of climate variability and tracer analysis [25]. In this study, EOF analysis was applied to the monthly mean TOVMR dataset over East Asia $\left(80^{\circ} \mathrm{E}-140^{\circ} \mathrm{E}\right.$, $10^{\circ} \mathrm{N}-50^{\circ} \mathrm{N}$ ) from March 1996 to June 2003 to retrieve the dominant spatiotemporal modes of tropospheric ozone over East Asia. 


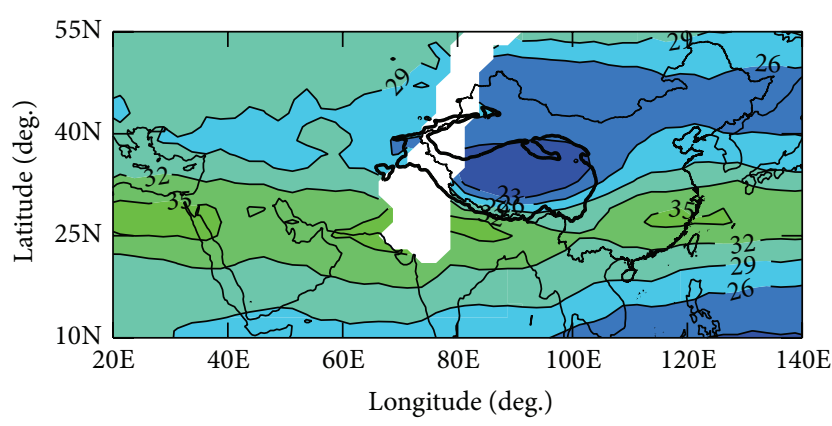

(a) Jan.

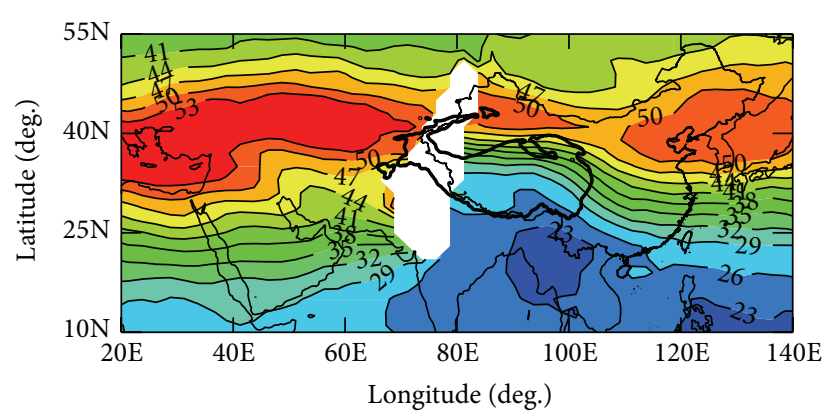

(c) Jul.

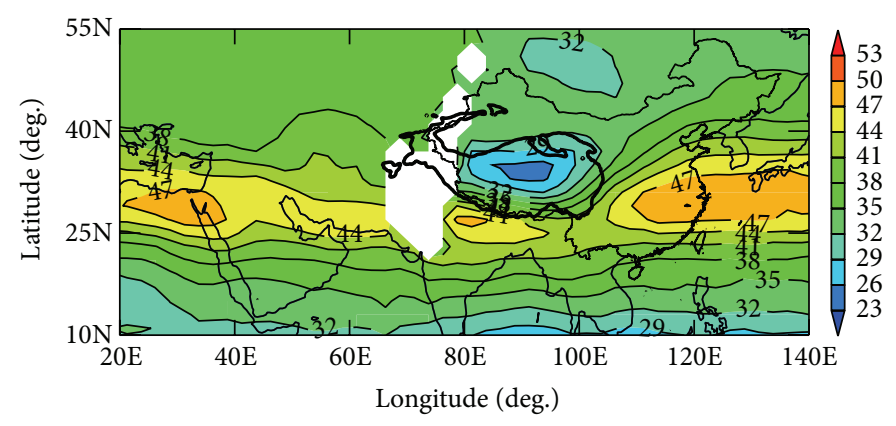

(b) Apr.

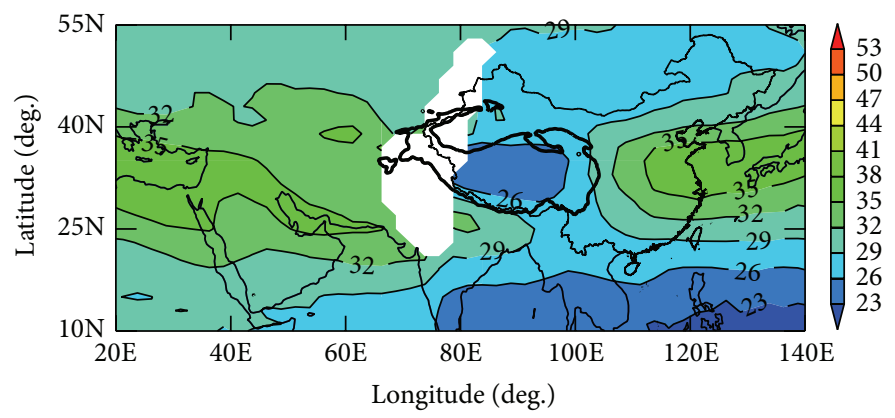

(d) Oct.

FIGURE 1: Monthly mean tropospheric column ozone (TCO) (unit: Dobson unit (DU)) from GOME (Global Ozone Monitoring Experiment) measurements between March 1996 and June 2003. GOME data are unavailable over the white area due to the lack of downlinking of GOME data to ground stations. The dark thick contours are coastline and the edge of Tibetan Plateau.

\section{The Seasonality of Tropospheric Ozone}

In winter (Figure 1(a)), high values of TCO (>32 DU) were present along a zonal belt around $30^{\circ} \mathrm{N}$ and there were low values of TCO $(<26 \mathrm{DU})$ over the Tibetan Plateau and northern China. In spring (Figure 1(b)), TCO was enhanced ( $>47 \mathrm{DU})$ along a zonal belt around $30-35^{\circ} \mathrm{N}$, due to stratosphere-troposphere exchange (STE), which predominantly occurs at this time of the year within this zonal belt [26]. In summer (Figure 1(c)), the belt of enhanced TCO (greater than $50 \mathrm{DU}$ ) moved northward to around $40^{\circ} \mathrm{N}$. Here, TCO shows the highest values throughout the year. Some studies have attributed this large increase in ozone in summer to its photochemical production, which is enhanced by the presence of anthropogenic pollution, biogenic volatile organic compounds, and $\mathrm{NO}_{x}[26,27]$. In autumn (Figure $1(\mathrm{~d})$ ), the TCO rapidly decreased and the belt of high TCO moved back towards the lower latitudes. GOME data were not available over Northern India and west of the Himalayas due to a lack of downlinking of GOME data to ground stations; thus these areas are shown in white in Figure 1.

Note that TCO was lower over the Tibetan Plateau than over other regions in the same latitudes in East Asia during the year. This tropospheric ozone anomaly is sufficiently shown to be clearly noticeable even in total ozone column measurements [28]. The anomaly low TCO over the Tibetan Plateau mainly occurs because of both the unique topography of the area and the tropopause height, which together determine the vertical extent of the tropospheric air column. With elevations up to almost the middle troposphere, the Tibetan Plateau (which extends over $27^{\circ} \mathrm{N}-45^{\circ} \mathrm{N}, 70^{\circ} \mathrm{E}-105^{\circ} \mathrm{E}$ at an average elevation of $\sim 4 \mathrm{~km}$ ) has a much shorter tropospheric air column over it than that in other regions at the same latitude. Further, the tropopause pressure over the Tibetan Plateau is lower, which means the tropopause is higher (Figure 2) over this region than at similar latitudes elsewhere in East Asia; this is especially true in summer (Figure 2(c)) as a result of the onset of Asian summer monsoon. Therefore, in order to reduce the influence of topography and tropopause height on tropospheric ozone, as detailed in the methods, the TCO was converted to TOVMR by using the tropopause and surface pressure data from NCEP.

The seasonality of TOVMR (Figure 3 ) is similar to that of TCO (Figure 1), except over the Tibetan Plateau, where TOVMR is higher than in other regions of the same latitude in East Asia. By excluding the effects of topography and tropopause height, TOVMR has certain advantages over TCO in studying the tropospheric ozone over East Asia. So, the spatiotemporal variations of tropospheric ozone over East Asia were investigated using TOVMR and are described in the following.

\section{EOF Analysis of TOVMR}

The two dominant spatial modes of monthly mean TOVMR from March 1996 to June 2003 over East Asia $\left(80^{\circ} \mathrm{E}-140^{\circ} \mathrm{E}\right.$, $10^{\circ} \mathrm{N}-50^{\circ} \mathrm{N}$ ) retrieved by EOF analysis (EOF1 and EOF2; Figures 4(a) and 4(b), resp.), along with their associated time 


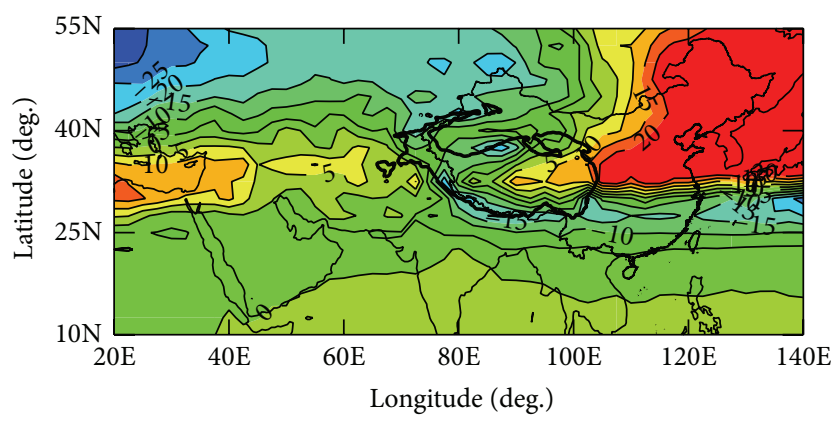

(a) Jan.

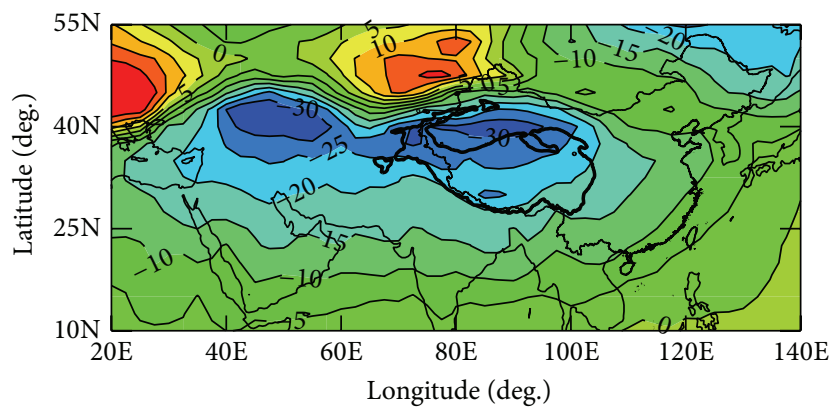

(c) Jul.

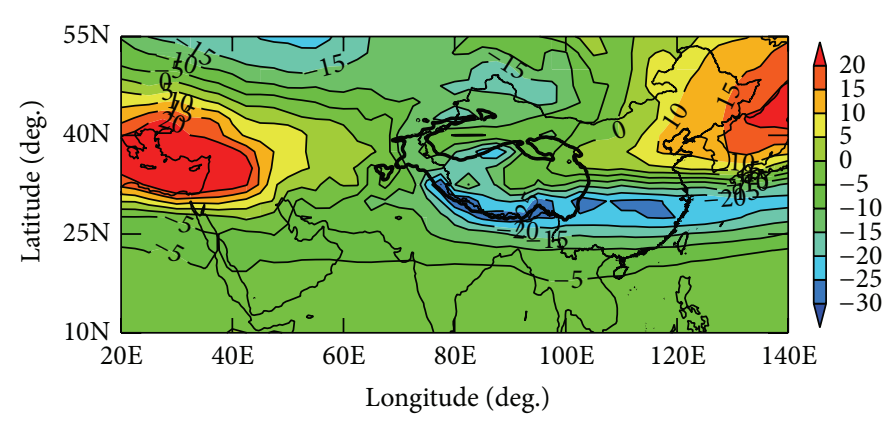

(b) Apr.

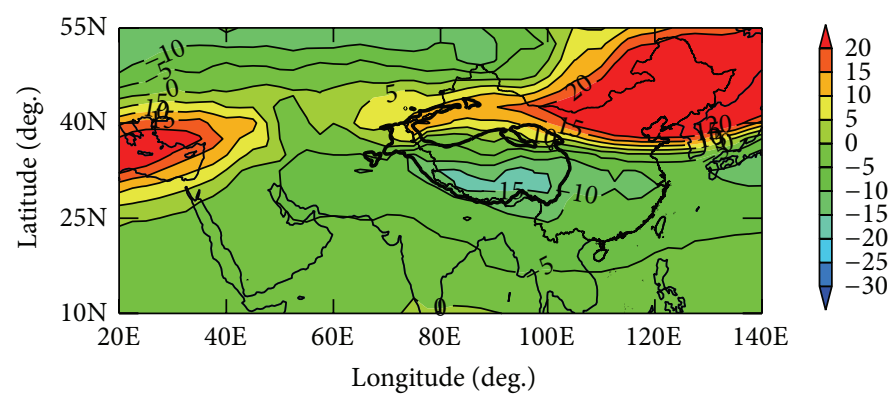

(d) Oct.

FIgURE 2: The same as Figure 1, but for zonal deviations of tropopause pressure (unit: hPa).

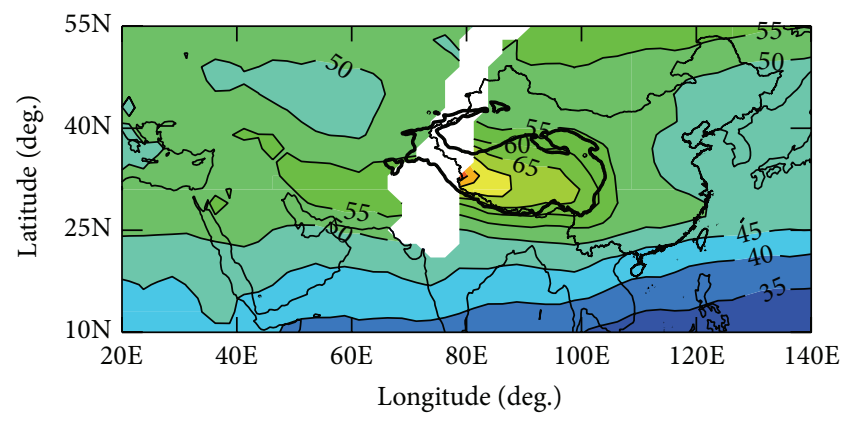

(a) Jan.

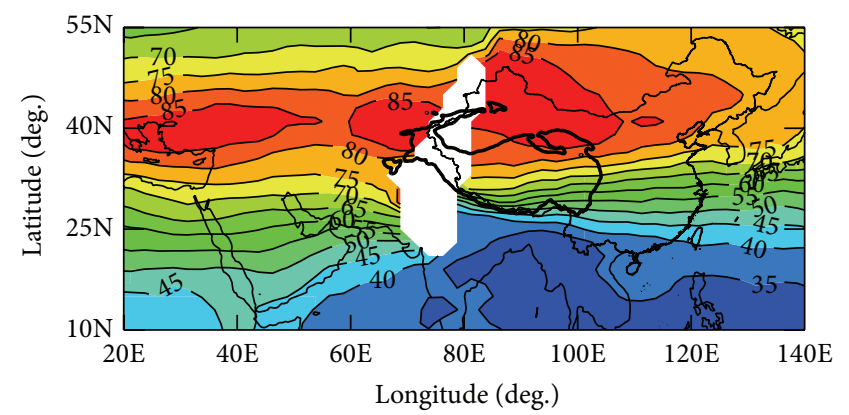

(c) Jul.

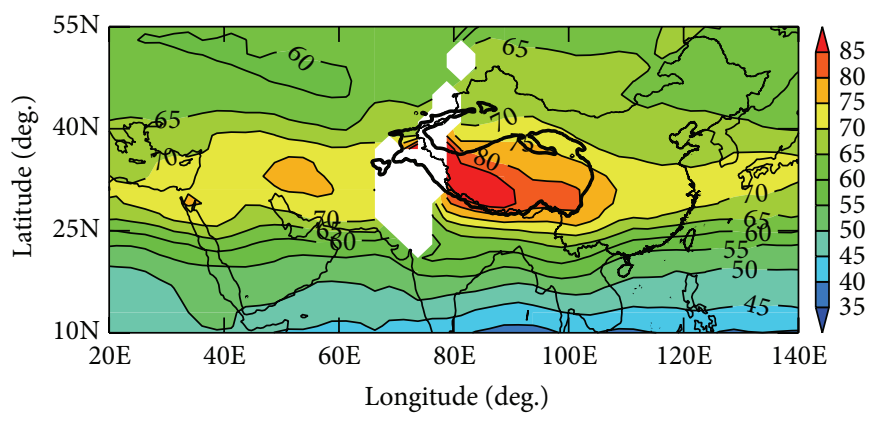

(b) Apr.

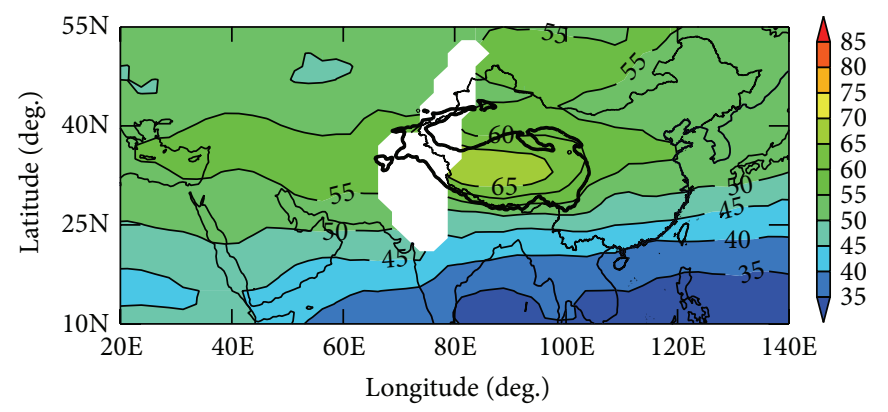

(d) Oct.

FigURE 3: The same as Figure 1, but for tropospheric ozone volume mixing ratio (TOVMR, unit: ppbv).

series (PC1 and PC2; Figures 4(c) and 4(d), resp.), together explained $\sim 90 \%$ of the spatiotemporal ozone variability in East Asia. This means that the major characteristics of tropospheric ozone were captured by these two modes. Both modes satisfied North's criteria [29] and have actual physical meaning.
4.1. The First EOF Mode (EOF1). The EOF1 (Figure 4(a)) explained $61.5 \%$ of the variance in ozone variability, with same-sign values over the entire East Asia, suggesting that the main variability in TOVMR over the entire region is very likely dominated by the same mechanism. The PC1 time series suggested that the maxima occur in May-June and the 


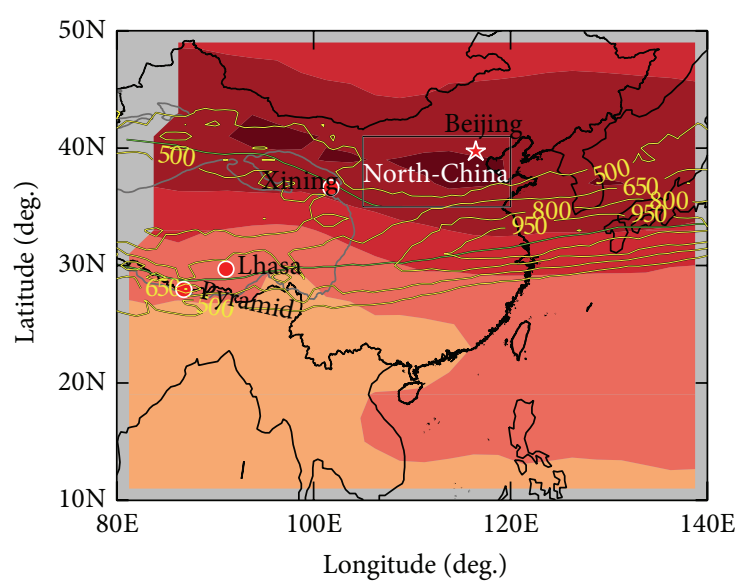

(a) $\mathrm{EOF} 1(61.5 \%)$

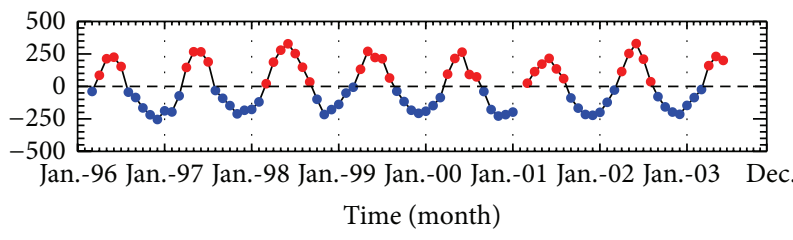

(c) $\mathrm{PCl}$

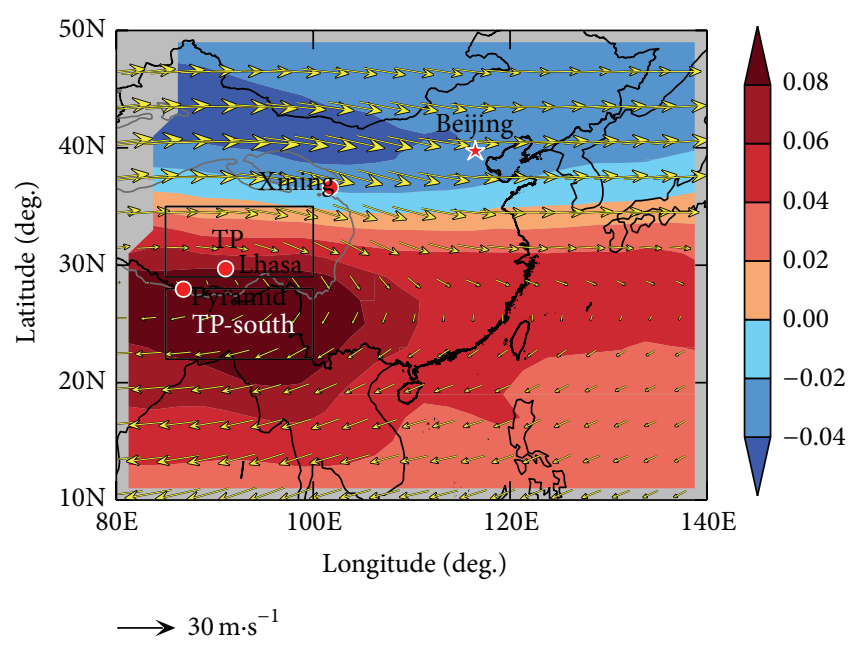

(b) EOF2 (29.2\%)

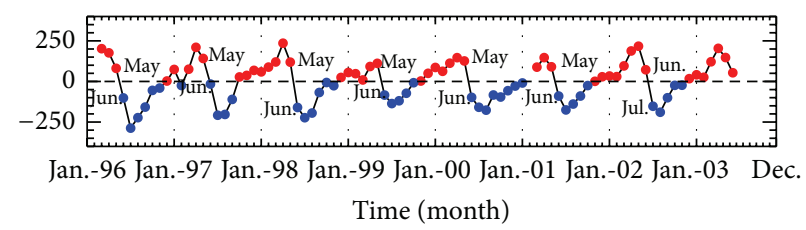

(d) PC2

Figure 4: Two dominant patterns retrieved from EOF analysis ((a) EOF1, (b) EOF2) of monthly mean TOVMR (color shaded) and their corresponding time series ((c) PC1, (d) PC2; red: positives, blue: negatives) between March 1996 and June 2003. The yellow contours in (a) are total westerly jet occurrence counts based on 6-hourly ERA-interim data, and the thick green lines show the position of maximum occurrence. Summer (June-August) winds at $200 \mathrm{hPa}$ for the same period are shown by vectors in (b). The red star is the location of Beijing and the red dots are locations of Lhasa, Xining, and Pyramid (Nepal); they are four ozonesonde stations. The square in (a) is the area of northern China; the square in (b) is southern Tibetan Plateau and the area to the south of Tibetan Plateau.

minima in November-December (Figure 4(c)). This indicates that the contribution of photochemical ozone production plays a significant role in modulating the seasonal variation of the averaged ozone concentration in the troposphere. However, the maxima did not occur in July-August when photochemical production was even stronger. We suspect that some dynamical processes must also be responsible for the formation of EOF1. It is noted that there was a belt of high values of EOF1 around $40^{\circ} \mathrm{N}$ (Figure 4(a)). The latitudinal location of the high-value belt is very close to that of the downward branch of the Brewer-Dobson circulation (BDC) in the midlatitudes, which is regarded to be a dominant avenue for stratosphere-to-troposphere ozone transport [30, 31]. Additionally, as a horizontal barrier which weakens the north-south exchange, the subtropical westerly jet further maintains the ozone-rich air, brought by the downward transport of the $\mathrm{BDC}$, around $40^{\circ} \mathrm{N}$. In the following sections, the correlations between the PC1 time series and the seasonal variation of BDC and westerly jet are analyzed.

4.1.1. The Correlation between EOF1 and BDC Intensity. The $\mathrm{BDC}$ is the meridional transport circulation system, which implies upward motion of air in the tropics and downward motion in the subtropics. Dobson [32] successfully explained the meridional distribution of ozone and water vapor by using the BDC, which is mainly driven by stratospheric planetary waves. As a representation of the planetary wave forcing, the vertical component of the Eliassen-Palm- (EP-) flux (EP-Fz) drives the $\mathrm{BDC}$ and further affects the meridional transport of ozone [33]. In the following text, we describe how we used the EP-Fz to study the relationship between the BDC and ozone variability in the region that had high levels of TOVMR in the EOF1 mode.

The three-dimensional EP-flux [34] was calculated based on the monthly mean ERA-interim zonal wind and temperature data. The mean EP-Fz within the region of high TOVMR values in EOF1 mode $\left(100 \mathrm{hPa}, 80-140^{\circ} \mathrm{E}, 35-45^{\circ} \mathrm{N}\right)$ was used to characterize the ozone transport from the stratosphere to the troposphere by the BDC. The EP-Fz was high in winter and low in summer (Figure 5(a)), suggesting that the BDC transports more ozone-rich air from lower latitudes to the higher latitudes in stratosphere in winter. However, the maximal tropospheric ozone occurred 5-7 months after the EP-Fz maximum, indicating that once stratospheric ozone has been transported from tropics to midlatitudes by the BDC, it takes several months to be transported through the tropopause and into the troposphere in the subtropics [30]. The lagged correlations between the EP-Fz and GOME tropospheric ozone (Figure 5(b)) indicate that the maximal tropospheric ozone seen in $\mathrm{PCl}$ occurred five months after the $\mathrm{EP}-\mathrm{Fz}$ 


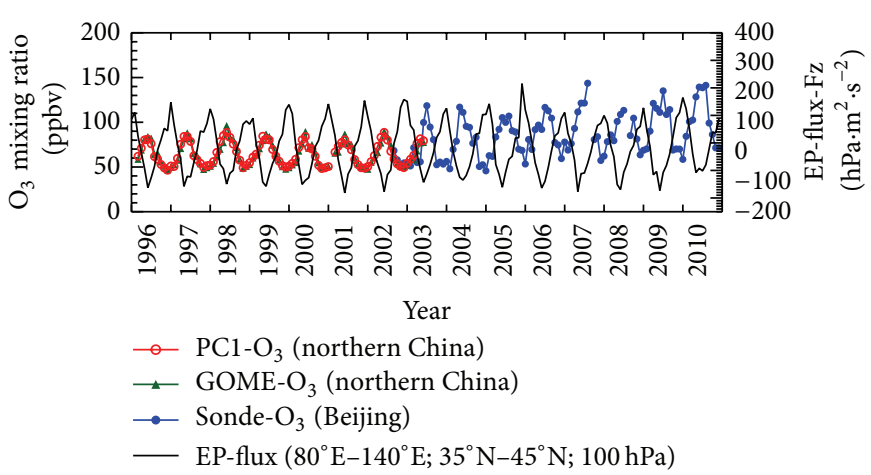

(a)

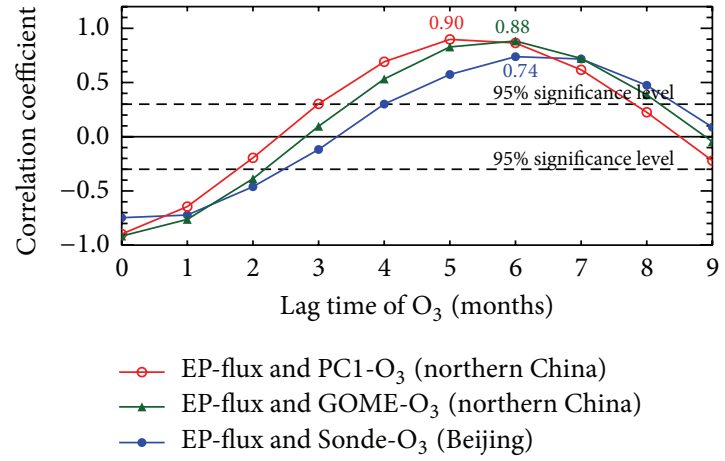

(b)

Figure 5: (a) Time series of the regional mean $\left(80^{\circ} \mathrm{E}-140^{\circ} \mathrm{E} ; 35^{\circ} \mathrm{N}-45^{\circ} \mathrm{N}\right)$ vertical EP-flux at $100 \mathrm{hPa}$ between January 1996 and December 2010, PC1 decomposed from GOME TOVMR (PC1-O 3 ) and GOME TOVMR $($ GOME-O 3 ) between March 1996 and June 2003 over northern China, and ozonesonde observed tropospheric ozone mixing ratio (Sonde- $\mathrm{O}_{3}$ ) over Beijing from September 2002 to December 2010. (b) Lag correlation coefficients between EP-flux and the time series of ozone (red: $\mathrm{PC1}-\mathrm{O}_{3}$ over northern China; green: GOME ozone over northern China; blue: ozonesonde over Beijing).

maximum $(r=0.9)$, and the maximal GOME ozone (without EOF analysis) occurred six months after the EP-Fz maximum $(r=0.88)$. Based on the ozonesonde measurements over Beijing, which is located in the region of high TOVMR values in EOF1 mode, the maximal tropospheric ozone over Beijing occurred six months after the EP-Fz maximum ( $r=0.74)$. The lagged correlations between the EP-Fz and tropospheric ozone (both satellite and ozonesonde) were significant at the 95\% confidence level, suggesting that the BDC does play an important role in the formation of the tropospheric ozone pattern seen in EOF1.

\subsubsection{The Correlation between EOF1 and the Subtropical} Westerly Jet. According to previous studies [35-37], the subtropical westerly jet can block the horizontal ozone exchange between high and low latitudes. Separated by high topography, the two maxima of the subtropical westerly jet occurrence (green lines in Figure 4(a)) exist on the northern and southern edges of the Tibetan Plateau. However, the high values of TOVMR in the EOF1 pattern only existed on the northern edge of the Tibetan Plateau; here, the ozone-rich air brought by the downward transport of the BDC from the stratosphere is blocked by the subtropical westerly jet and accumulates north of the jet.

As a result of BDC transportation and blocking effort of subtropical westerly jet, the high ozone produced by photochemical peaked in May-June. Although photochemical production was even stronger in the later July-August, the weakening of BDC transportation and the strength of subtropical westerly jet led to the decrease in ozone during this period.

4.2. The Second EOF Mode (EOF2). The EOF2 mode explained $29.2 \%$ of the variance, with an opposite-sign pattern on either side of $35^{\circ} \mathrm{N}$ (Figure 4(b)). The high values of TOVMR seen in EOF2 were mainly located to the south of the Tibetan Plateau and in the Bay of Bengal. The positive maxima of PC2 (Figure 4(d)) occurred in spring (April-May),

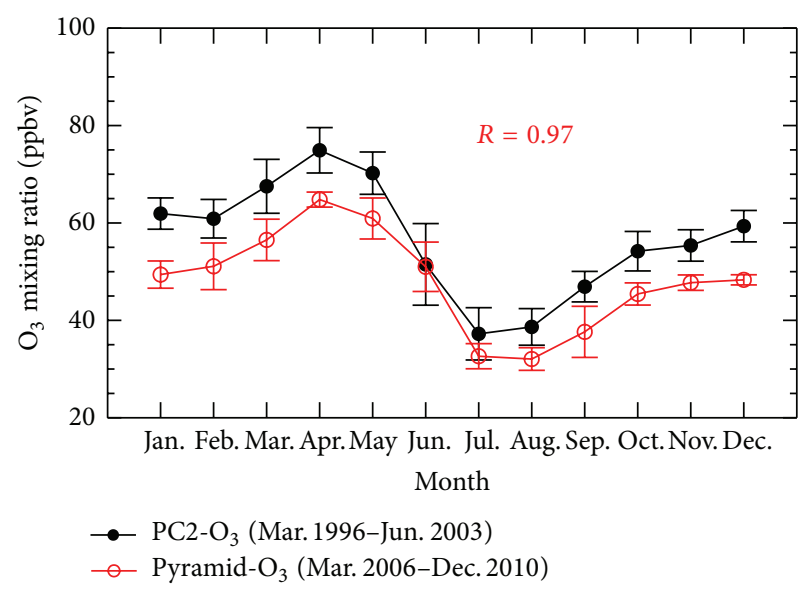

Figure 6: Seasonality of surface ozone at Pyramid station (Pyramid$\mathrm{O}_{3}$ ) from March 2006 to December 2010 and the regional mean (within $\pm 1^{\circ}$, centered at Pyramid station) PC2 decomposed from GOME TOVMR (PC2-O ${ }_{3}$ ) between March 1996 and June 2003. Error bars are standard deviations $( \pm \sigma)$.

and the negative minima occurred in summer (July-August). So, it can be concluded that tropospheric ozone, over the areas to the south of the Tibetan Plateau and in the Bay of Bengal, is higher in spring and lower in summer.

The PC2 changed rapidly from positive to negative in May-June, indicating that the tropospheric ozone over the area to the south of the Tibetan Plateau and in the Bay of Bengal decreased dramatically during this period. Since this region is located within the area of the summer monsoon anticyclone, which begins during May-June, the Asian summer monsoon could be the main reason for the observed EOF2 mode.

There were similar trends $(r=0.97)$ between the PC2 pattern and surface observations from Pyramid, Nepal (5079 $\mathrm{m}$ a.s.l.; located on the southern edge of the Tibetan Plateau) (Figure 6). Because PC2 describes tropospheric ozone and the Pyramid observations only recorded surface 


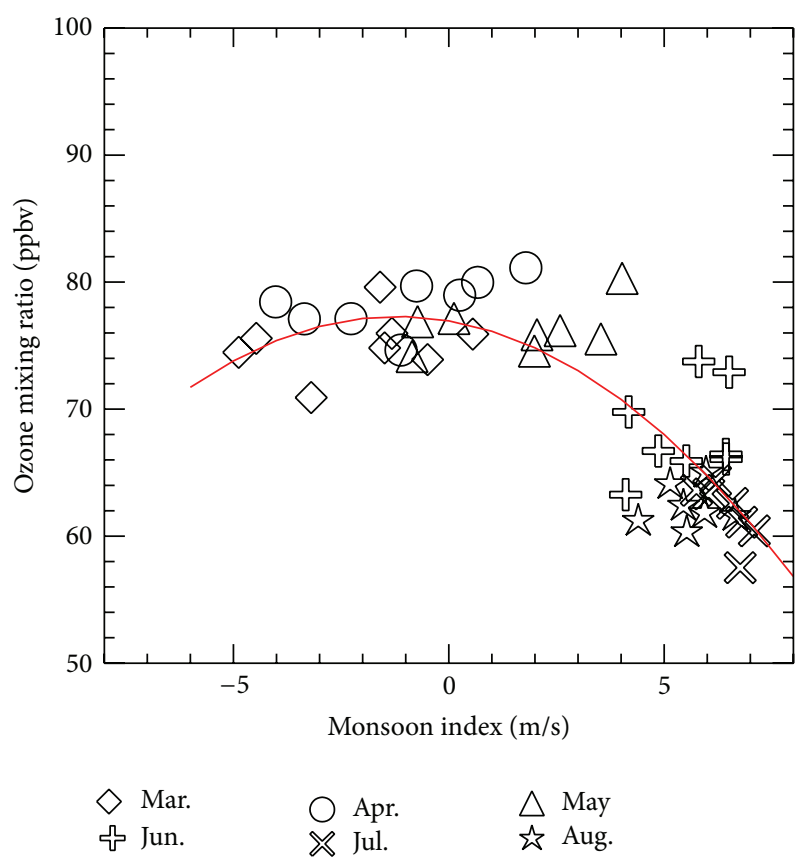

(a) $\mathrm{TP}$

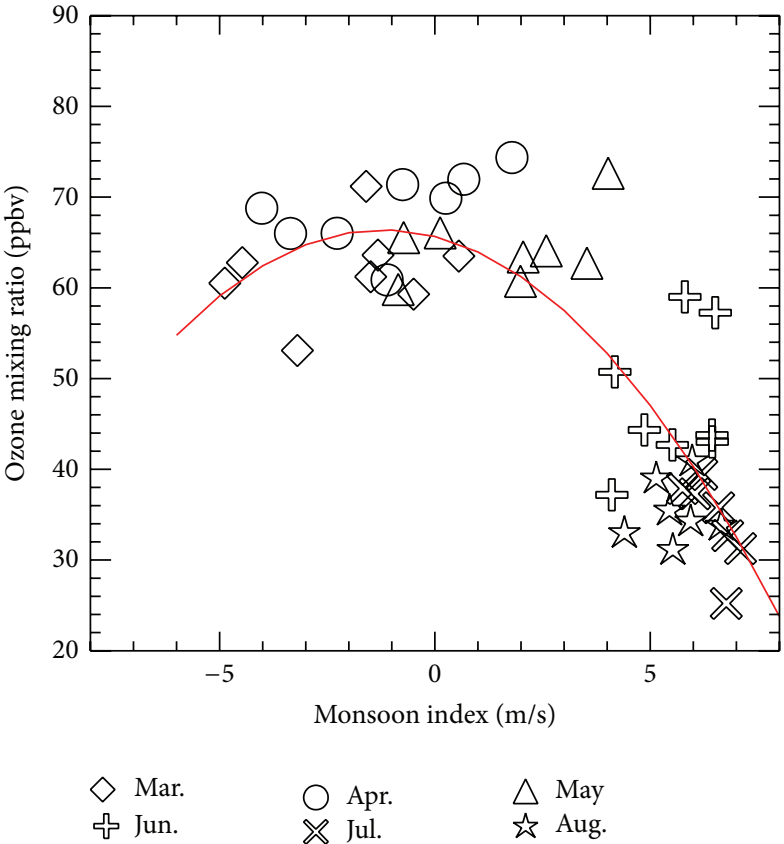

(b) TP-south

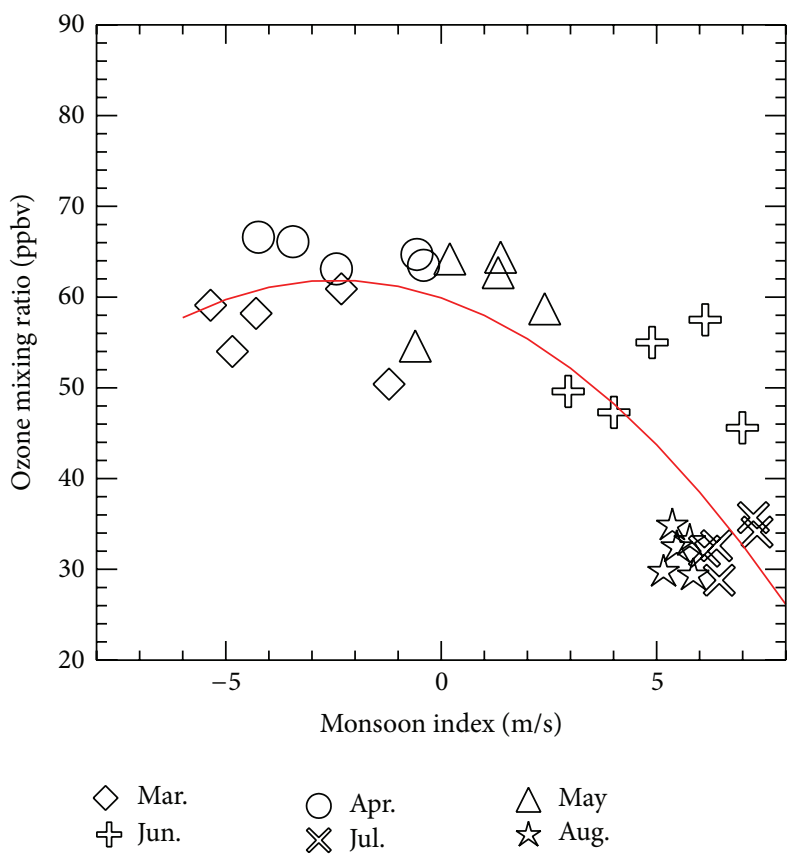

(c) Pyramid- $\mathrm{O}_{3}$

Figure 7: Correlation between the Indian Monsoon index and $\mathrm{PC} 2-\mathrm{O}_{3}$ over (a) the Tibetan Plateau and (b) south of the Tibetan Plateau between March 1996 and June 2003, and (c) the correlation between the Indian Monsoon index and surface observations of ozone from Pyramid between March 2006 and December 2010.

ozone concentrations, PC2 was generally higher than the ozone observations from Pyramid, except in June, when they were almost equal. This equality can be attributed to the onset of the Asian summer monsoon, which transports air containing less ozone into the region in June; as a result, the tropospheric ozone is reduced and becomes almost equivalent to the surface ozone.
A minimum ozone concentration has been shown to occur in the middle troposphere over the Tibetan Plateau in June, simultaneous with the onset of the Asian summer monsoon [38]. It was suggested that the monsoon anticyclone causes air containing less ozone to be transported from the lower to middle and higher troposphere, by strong upward movements over the Bay of Bengal, driving the air 
to the Tibetan Plateau. The tropospheric ozone over Pyramid rapidly decreased to be almost equal to surface observations during this process (Figure 6). Blocked by the westerly jet on the northern side of the Tibetan Plateau, the ozone accumulates over the southeast of the Plateau. The existence of this ozone minimum in the middle troposphere over the Tibetan Plateau is consistent with the ozone minimum over Pyramid, resulting from the onset of the Asian summer monsoon.

The PC2 over the Tibetan Plateau and to the south of the Tibetan Plateau and the surface ozone observations from Pyramid appear closely related to the South Asian summer monsoon (Figures 7(a)-7(c), resp.). However, the relationships between the monsoon and ozone at each location were not simply linear. During March-May, the enhanced photochemistry and ozone exchange between the stratosphere and troposphere over the Tibetan Plateau increased the tropospheric ozone. With the onset of the Asian summer monsoon, during the months May-June, the tropospheric ozone levels over the Tibetan Plateau and to the south of the Tibetan Plateau dramatically decreased, as explained above. Further, the increase in precipitation, due to enhanced convection during the summer monsoon, also played a role in the decrease in ozone.

\section{Conclusions}

The spatiotemporal characteristics of tropospheric ozone over East Asia were analyzed using tropospheric ozone data from the GOME satellite and meteorological datasets from the ERA-interim reanalysis dataset. Generally, the TCO was the lowest in winter and the highest in summer, with a TCO minimum present over the Tibetan Plateau. There was a belt of high TCO, which occurred at $30^{\circ} \mathrm{N}$ in winter and moved northward to $40^{\circ} \mathrm{N}$ in summer. To reduce the influence of topography and the tropopause height on TCO, we calculated the average ozone concentration in the troposphere (TOVMR). The seasonality of TOVMR was similar to that of TCO, except that the TOVMR over the Tibetan Plateau was the highest in East Asia throughout the year.

EOF analysis was applied to characterize the spatiotemporal variations in TOVMR. The two dominant spatial patterns (EOF1 and EOF2) explained $\sim 90 \%$ of the total variance in TOVMR. The EOF1 mode, which explained $61.5 \%$ of the total variance, showed a same-sign distribution over all of East Asia, with a belt of enhanced ozone concentrations around $40^{\circ} \mathrm{N}$. The PC1 time series showed that the averaged ozone concentration in the troposphere was higher in summer and lower in winter, indicating the contribution of photochemical ozone production. Further analysis suggested that the high-value belt of ozone concentrations around $40^{\circ} \mathrm{N}$ was highly related to the vertical transport of ozone-rich air from the stratosphere to the troposphere by the downward branch of the BDC. This ozone-rich air is then blocked by the subtropical westerly jet and accumulates to the north of the jet.

The EOF2 mode explained $29.2 \%$ of the total variance, with an opposite-sign pattern on the northern and southern sides of $35^{\circ} \mathrm{N}$. The high values of TOVMR in EOF2 were located to the south of the Tibetan Plateau and in the Bay of Bengal. Tropospheric ozone over this region decreased dramatically in May-June, when the anticyclonic circulation transports ozone-poor air from the upwelling area over the Bay of Bengal towards the Tibetan Plateau during the onset of the Asian summer monsoon. The high correlations between the Monsoon-Hadley index (MHI) and ozone over three locations in this region confirmed the dominant contribution of the Asian summer monsoon to the EOF2 mode.

To quantify the relative contributions of photochemistry and transport to the tropospheric ozone budget and its seasonal variation shown in EOF1, a numerical study based on the chemistry transport models should be performed in the future.

\section{Conflict of Interests}

The authors declare that there is no conflict of interests regarding the publication of this paper.

\section{Acknowledgments}

This work was funded by the National Science Foundation of China (Grant nos. 41305127 and 41105025) and the Dragon 3 Programme (ID: 10577). The authors thank Dr. Xiong Liu for providing the GOME data. The European Centre for Medium-Range Weather Forecasts (ECMWF) is acknowledged for meteorological data support.

\section{References}

[1] J. Fishman, S. Solomon, and P. J. Crutzen, "Observational and theoretical evidence in support of a significant in-situ photochemical source of tropospheric ozone," Tellus, vol. 31, no. 5, pp. 432-446, 1979.

[2] T. K. Berntsen, G. Myhre, F. Stordal, and I. S. A. Isaksen, "Time evolution of tropospheric ozone and its radiative forcing," Journal of Geophysical Research D: Atmospheres, vol. 105, no. 7, pp. 8915-8930, 2000.

[3] H. Levy II, "Normal atmosphere: large radical and formaldehyde concentrations predicted," Science, vol. 173, no. 3992, pp. 141-143, 1971.

[4] V. P. Aneja and Z. Li, "Characterization of ozone at high elevation in the eastern United States: trends, seasonal variations, and exposure," Journal of Geophysical Research, vol. 97, no. 9, pp. 9873-9888, 1992.

[5] X. Tie, G. P. Brasseur, C. Zhao et al., "Chemical characterization of air pollution in Eastern China and the Eastern United States," Atmospheric Environment, vol. 40, no. 14, pp. 2607-2625, 2006.

[6] T. Berntsen, I. S. A. Isaksen, W.-C. Wang, and X.-Z. Liang, "Impacts of increased anthropogenic emissions in Asia on tropospheric ozone and climate: a global 3-D model study," Tellus, Series B: Chemical and Physical Meteorology, vol. 48, no. 1, pp. 13-32, 1996.

[7] J. H. Kim and H. Lee, "What causes the springtime tropospheric ozone maximum over Northeast Asia?" Advances in Atmospheric Sciences, vol. 27, no. 3, pp. 543-551, 2010.

[8] K. Yamaji, T. Ohara, I. Uno, H. Tanimoto, J.-I. Kurokawa, and H. Akimoto, "Analysis of the seasonal variation of ozone in 
the boundary layer in East Asia using the Community Multiscale Air Quality model: what controls surface ozone levels over Japan?" Atmospheric Environment, vol. 40, no. 10, pp. 1856-1868, 2006.

[9] M. L. Buker, M. H. Hitchman, G. J. Tripoli, R. B. Pierce, E. V. Browell, and M. A. Avery, "Resolution dependence of crosstropopause ozone transport over east Asia," Journal of Geophysical Research: Atmospheres, vol. 110, no. 3, Article ID D03107, 2005.

[10] Y. Wang, P. Konopka, Y. Liu et al., "Tropospheric ozone trend over Beijing from 2002-2010: ozonesonde measurements and modeling analysis," Atmospheric Chemistry and Physics, vol. 12, no. 18, pp. 8389-8399, 2012.

[11] H. Liu, D. J. Jacob, L. Y. Chan et al., "Sources of tropospheric ozone along the Asian Pacific Rim: an analysis of ozonesonde observations," Journal of Geophysical Research: Atmospheres, vol. 107, no. 21, article 4573, 2002.

[12] J. Worden, D. B. A. Jones, J. Liu et al., "Observed vertical distribution of tropospheric ozone during the Asian summertime monsoon," Journal of Geophysical Research D: Atmospheres, vol. 114, no. 13, Article ID D13304, 2009.

[13] K. Yamaji, T. Ohara, I. Uno, J. I. Kurokawa, P. Pochanart, and H. Akimoto, "Future prediction of surface ozone over east Asia using Models-3 Community Multiscale Air Quality Modeling System and Regional Emission Inventory in Asia," Journal of Geophysical Research D: Atmospheres, vol. 113, no. 8, Article ID D08306, 2008.

[14] W. J. Randel, M. Park, L. Emmons et al., "Asian monsoon transport of pollution to the stratosphere," Science, vol. 328, no. 5978, pp. 611-613, 2010.

[15] K. V. Chance, J. P. Burrows, D. Perner, and W. Schneider, "Satellite measurements of atmospheric ozone profiles, including tropospheric ozone, from ultraviolet/visible measurements in the nadir geometry: a potential method to retrieve tropospheric ozone," Journal of Quantitative Spectroscopy and Radiative Transfer, vol. 57, no. 4, pp. 467-476, 1997.

[16] X. Liu, K. Chance, C. E. Sioris et al., "Ozone profile and tropospheric ozone retrievals from the Global Ozone Monitoring Experiment: algorithm description and validation," Journal of Geophysical Research: Atmospheres, vol. 110, no. 20, Article ID D20307, 2005.

[17] X. Liu, K. Chance, C. E. Sioris et al., "First directly retrieved global distribution of tropospheric column ozone from GOME: comparison with the GEOS-CHEM model," Journal of Geophysical Research: Atmospheres, vol. 111, no. D2, 2006.

[18] X. Liu, K. Chance, and T. P. Kurosu, "Improved ozone profile retrievals from GOME data with degradation correction in reflectance," Atmospheric Chemistry and Physics, vol. 7, no. 6, pp. 1575-1583, 2007.

[19] X. Liu, K. Chance, C. E. Sioris, T. P. Kurosu, and M. J. Newchurch, "Intercomparison of GOME, ozonesonde, and SAGE II measurements of ozone: demonstration of the need to homogenize available ozonesonde data sets," Journal of Geophysical Research D: Atmospheres, vol. 111, no. 14, Article ID D14305, 2006.

[20] Z. Cai, Y. Wang, X. Liu, X. Zheng, K. Chance, and Y. Liu, "Validation of GOME ozone profiles and tropospheric column ozone with ozonesonde over China," Journal of Applied Meteorological Science, vol. 20, pp. 337-345, 2009 (Chinese).

[21] J. R. Ziemke, S. Chandra, and P. K. Bhartia, “'Cloud slicing': a new technique to derive upper tropospheric ozone from satellite measurements," Journal of Geophysical Research: Atmospheres, vol. 106, no. 9, pp. 9853-9867, 2001.

[22] R. Schiemann, D. Lüthi, and C. Schär, "Seasonality and interannual variability of the westerley jet in the Tibetan Plateau region," Journal of Climate, vol. 22, no. 11, pp. 2940-2957, 2009.

[23] D. P. Dee, S. M. Uppala, A. J. Simmons et al., “The ERA-Interim reanalysis: Configuration and performance of the data assimilation system," Quarterly Journal of the Royal Meteorological Society, vol. 137, no. 656, pp. 553-597, 2011.

[24] B. N. Goswami, V. Krishnamurthy, and H. Annamalai, "A broad-scale circulation index for the interannual variability of the Indian summer monsoon," Quarterly Journal of the Royal Meteorological Society, vol. 125, no. 554, pp. 611-633, 1999.

[25] A. Hannachi, I. T. Jolliffe, and D. B. Stephenson, "Empirical orthogonal functions and related techniques in atmospheric science: a review," International Journal of Climatology, vol. 27, no. 9, pp. 1119-1152, 2007.

[26] J. R. Ziemke, S. Chandra, B. N. Duncan et al., "Tropospheric ozone determined from Aura OMI and MLS: evaluation of measurements and comparison with the Global Modeling Initiative's Chemical Transport Model," Journal of Geophysical Research D: Atmospheres, vol. 111, no. 19, Article ID D19303, 2006.

[27] J. Fishman, A. E. Wozniak, and J. K. Creilson, "Global distribution of tropospheric ozone from satellite measurements using the empirically corrected tropospheric ozone residual technique: identification of the regional aspects of air pollution," Atmospheric Chemistry and Physics, vol. 3, no. 4, pp. 893-907, 2003.

[28] P. Kiss, R. Müller, and I. M. Jánosi, "Long-range correlations of extrapolar total ozone are determined by the global atmospheric circulation," Nonlinear Processes in Geophysics, vol. 14, no. 4, pp. 435-442, 2007.

[29] G. R. North, T. L. Bell, R. F. Cahalan, and F. J. Moeng, "Sampling errors in the estimation of empirical orthogonal functions," Monthly Weather Review, vol. 110, no. 7, pp. 699-706, 1982.

[30] J. R. Holton, P. H. Haynes, M. E. McIntyre, A. R. Douglass, R. B. Rood, and L. Pfister, "Stratosphere-troposphere exchange," Reviews of Geophysics, vol. 33, no. 4, pp. 403-439, 1995.

[31] Y. Liu, C. X. Liu, H. P. Wang et al., "Atmospheric tracers during the 2003-2004 stratospheric warming event and impact of ozone intrusions in the troposphere," Atmospheric Chemistry and Physics, vol. 9, no. 6, pp. 2157-2170, 2009.

[32] G. M. B. Dobson, "Origin and distribution of the polyatomic molecules in the atmosphere," Proceedings of the Royal Society of London A: Mathematical, Physical and Engineering Sciences, vol. 236, no. 1205, pp. 187-193, 1956.

[33] W. J. Randel, F. Wu, and R. Stolarski, "Changes in column ozone correlated with the stratospheric EP flux," Journal of the Meteorological Society of Japan, vol. 80, no. 4 B, pp. 849-862, 2002.

[34] R. A. Plumb, "On the three-dimensional propagation of stationary waves," Journal of the Atmospheric Sciences, vol. 42, no. 3, pp. 217-229, 1985.

[35] C. Liu, Y. Liu, Z. Cai, S. Gao, D. Lu, and E. Kyrölä, “A MaddenJulian oscillation-triggered record ozone minimum over the Tibetan plateau in December 2003 and its association with stratospheric 'low-ozone pockets"' Geophysical Research Letters, vol. 36, no. 15, Article ID L15830, 2009. 
[36] C. Liu, Y. Liu, Z. Cai et al., "Dynamic formation of extreme ozone minimum events over the Tibetan Plateau during northern winters 1987-2001," Journal of Geophysical Research D: Atmospheres, vol. 115, no. 18, Article ID D18311, 2010.

[37] J. Bian, "Features of ozone mini-hole events over the Tibetan Plateau," Advances in Atmospheric Sciences, vol. 26, no. 2, pp. 305-311, 2009.

[38] Y. Liu, Y. Wang, X. Liu, Z. Cai, and K. Chance, "Tibetan middle tropospheric ozone minimum in June discovered from GOME observations," Geophysical Research Letters, vol. 36, Article ID L05814, 2009. 

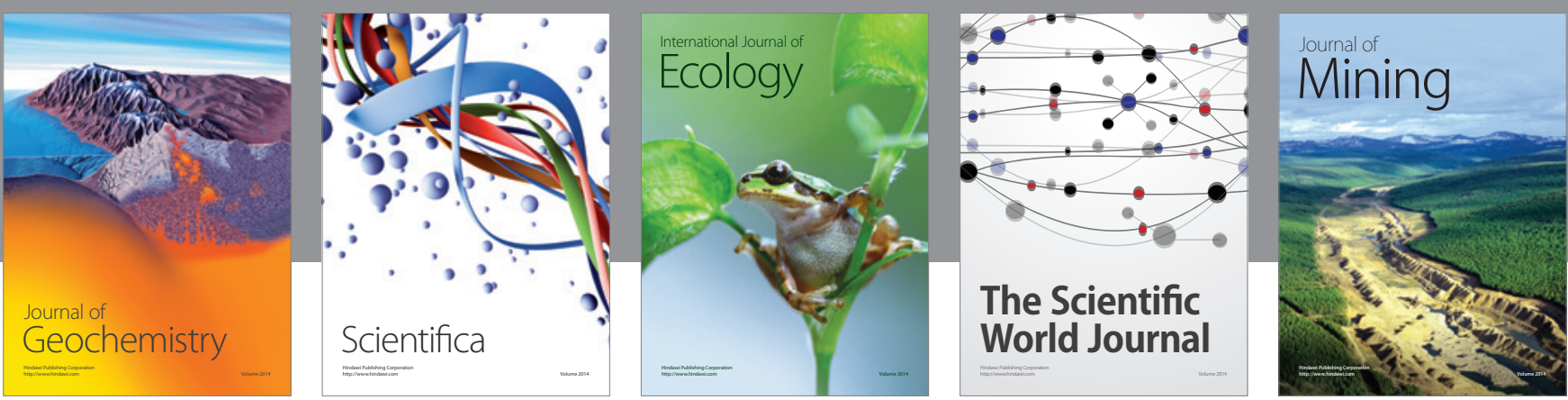

The Scientific World Journal
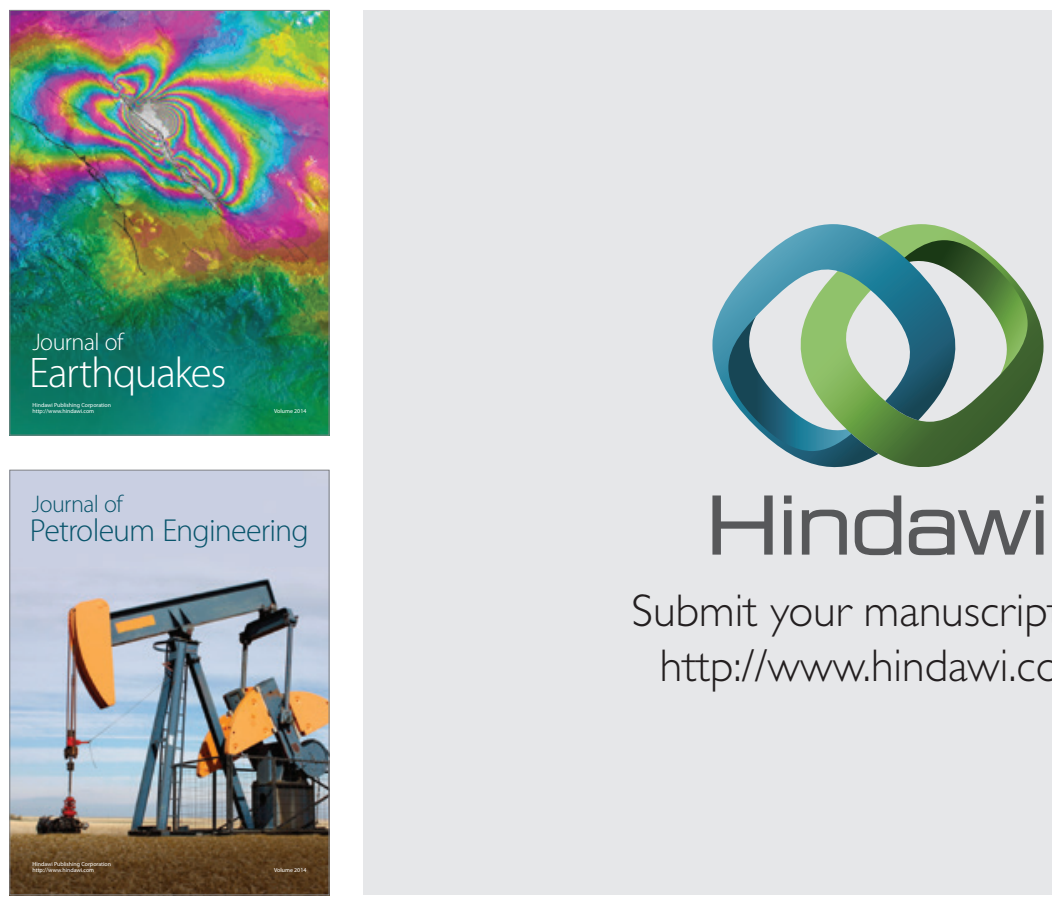

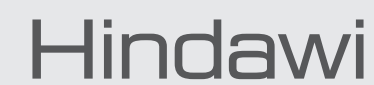

Submit your manuscripts at

http://www.hindawi.com
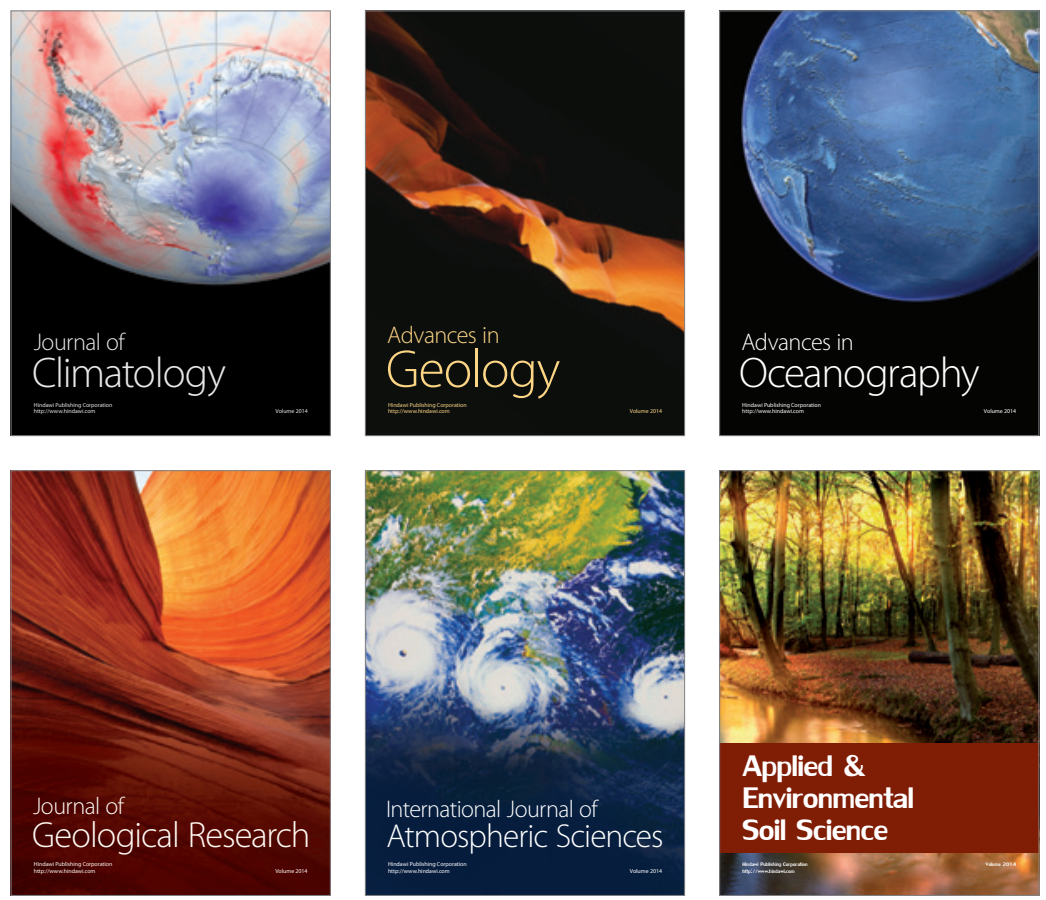
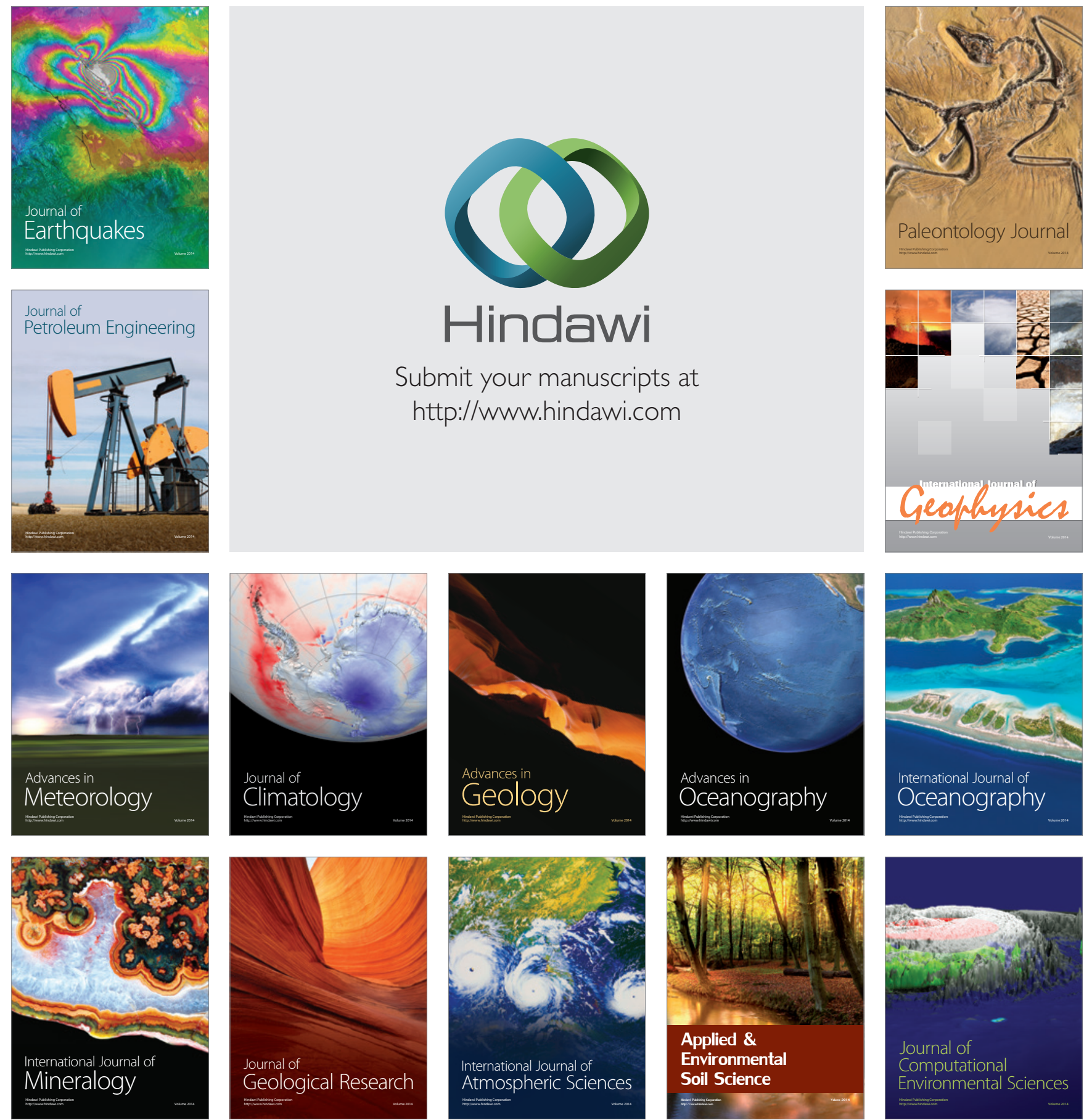